\title{
A NOVEL DESIGN OF 17.5 KV HV FEEDTHROUGH FOR ARJUNA 2.0
}

\section{DESAIN TERBARU HV FEEDTHROUGH 17.5 KV UNTUK ARJUNA 2.0}

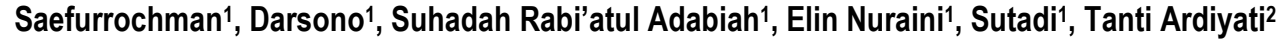 \\ ${ }^{1}$ Center for Accelerator Scince and Technology - National Nuclear Energy Agency of Indonesia, Jalan \\ Babarsari Kotak Pos 6101 Ykbb, Yogyakarta, Indonesia 55281 \\ ${ }^{2}$ Center for Nuclear Facilities Engineering - National Nuclear Energy Agency of Indonesia, Kawasan \\ Puspiptek Gedung 71 Lantai 2, Tangerang Selatan, Indonesia \\ E-mail : saefurrochman@batan.go.id
}

Received 1 February 2021, Received in revised form 21 February 2021, Accepted 23 February 2021

\begin{abstract}
A NOVEL DESIGN OF 17.5 KV HV FEEDTHROUGH FOR ARJUNA 2.0. A novel design of the $17.5 \mathrm{kV} \mathrm{HV}$ feedthrough for Arjuna 2.0 Cockcroft Walton generator has been proposed. The HV feedthrough is used for connecting the output of RF transformer oscillator (in the outside of horizontal vessel) with the input of voltage multiplier (inside of horizontal vessel) of the Cockcroft Walton generator. It was equipped with covers on left and right side. The designed feedthrough was simple, compact, and easy to manufacture, and had high performance to prevent flashover. It was made from teflon (PTFE) and solid copper, which have high dielectric strength, capable of withstanding press loads. The shortest distance between grounding with conductor radially was $43.25 \mathrm{~mm}$, and $253.5 \mathrm{~mm}$ for feedthrough surface. The design was verified by Finite Element Method software and followed by performance testing. According to the simulation, high voltage stresses about $16 \mathrm{kV}$ to $17.5 \mathrm{kV}$ are observed at feedthrough conductor, while the voltage stress at the feedthrough flange is considerably smaller, about $0 \mathrm{kV}$ to $3 \mathrm{kV}$. The electric field of the covered feedthrough is lower than the coverless feedthrough. The highest and lowest electric fields are $1.26 \times 10^{6} \mathrm{~V} / \mathrm{m}$ and $1 \times 10^{5} \mathrm{~V} / \mathrm{m}$, respectively. Furthermore, feedthrough has been tested up to $120 \mathrm{kV}$ and no discharge occurred. The design can be operated at $17.5 \mathrm{kV}$ and has been successfully installed on Arjuna 2.0 Cockcroft Walton generator.
\end{abstract}

Keywords: feedthrough, Arjuna 2.0, electric field, Cockcroft Walton

\section{ABSTRAK}

DESAIN TERBARU HV FEEDTHROUGH 17,5 KV UNTUK ARJUNA 2.0. Desain terbaru dari feedthrough $17,5 \mathrm{kV}$ untuk generator Cockcroft Walton Arjuna 2.0 telah diusulkan. Feedthrough digunakan untuk menghubungkan keluaran osilator transformer RF (di luar bejana horisontal) dengan masukan pengali tegangan (di dalam bejana horisontal) dari generator Cockcroft Walton. Feedthrough ini dilengkapi dengan penutup pada sisi kiri dan kanannya. Feedthrough yang didesain sederhana, kompak, dan mudah dibuat, serta memiliki kinerja yang tinggi untuk mencegah terjadinya flashover. Feedthrough terbuat dari teflon (PTFE) dan tembaga padat, yang memiliki kekuatan dielektrik yang tinggi, mampu menahan beban tekan, dan mudah dibuat. Jarak terpendek antara ground dan konduktor secara radial adalah 43,25 mm dan 253,5 mm untuk permukaan feedthrough. Desain ini diverifikasi oleh perangkat lunak Finite Element Method kemudian dilanjutkan dengan pengujian kinerja. Berdasarkan simulasi, tekanan tegangannya tinggi sekitar $16 \mathrm{kV}$ hingga $17,5 \mathrm{kV}$ pada konduktor feedthrough dan 0 hingga $3 \mathrm{kV}$ pada flens feedthrough. Medan listrik feedthrough dengan tutup lebih rendah dari feedthrough tanpa tutup. Medan listrik tertinggi dan terendah masing-masing adalah $1.26 \times 10^{6} \mathrm{~V} / \mathrm{m}$ dan (sekitar) $1 \times 10^{5} \mathrm{~V} / \mathrm{m}$. Selanjutnya, feedthrough telah diuji hingga $120 \mathrm{kV}$ dan tidak terjadi pelepasan. Desain ini dapat dioperasikan dengan daya $17,5 \mathrm{kV}$ dan telah berhasil dipasang pada generator Cockcroft Walton Arjuna 2.0.

Kata Kunci: Feedthrough, Arjuna 2.0, medan listrik, Cockcroft Walton

\section{INTRODUCTION}

Center for Accelerator Science and Technology - National Nuclear Energy Agency Indonesia (CAST) is developing an electron beam accelerator for pre-vulcanization natural rubber latex (Arjuna 2.0) with energy of $300 \mathrm{keV} / 20 \mathrm{~mA}$ [1]. In Arjuna 2.0, $300 \mathrm{kV}$ of Cockcroft Walton generator is used to accelerate electron beam. Slightly different from the widely used Cockcroft Walton generator, the voltage multiplier of the Cockcroft Walton generator is installed horizontally with the aim to simplify the maintenance. 
Jurnal Iptek Nuklir Ganendra

Ganendra Journal of Nuclear Science and Technology

Vol. 24 No. 1, January - 2021: 21-28

One of the important component of Cockcroft Walton is the feedthrough or bushing. It is a device used to carry current on certain voltage conditions through the ground barrier [2]. It is mounted in a fixed position and it has a connector from high voltage source to another device that is not in the same atmospheric pressure. It is applied in many electrical devices such as transformer [3], accelerator [4], fusion reactor [5], etc. It is made from insulator such as alumina and FRP [6], ceramic [7] and so on.

Feedthroughs have a variety of designs in terms of materials and shapes, which depends on their application. In a research conducted by N. Panklang, et.al., a simple feedthrough made of natural rubber and HDPE compounds is designed, to be used for transformer in open spaces [3]. Umeda, et.al. designed a half size mockup bushing which was fabricated from a ceramic ring connected to a kovar plate as a sealing metal. Simonim, et.al. designed a feedthrough in the form of a double layer of rings insulator. It was made of epoxy insulator and alumina ceramic which separates SF6 (0.6 MPa), air (1 MPa) and vacuum.

In this research, a different design of high voltage feedthrough is proposed. The designed feedthrough connects the output of RF transformer oscillator to the input of Cockcroft Walton voltage multiplier and it was operated at a voltage of $17.5 \mathrm{kV}$. The high voltage feedthrough was made from PTFE and solid copper. The PTFE (polytetrafluoroethylene) was selected as an insulator material due to their properties such as perfect insulating and dielectric properties, good thermal stability, and low thermal conductivity [8, 9]. Meanwhile, the advantage of solid PTFE is easy to be manufactured. The novelty is the shape of the feedthrough. The feedthrough is equipped with two covers to protect the connector from the electric field, so flashover and discharge will not occur. The aim of this research is to design a high voltage feedthrough operated at $17.5 \mathrm{kV}$ with a simple design, compact, easy to manufacture, highly performing, and is able to prevent flashover.

\section{METHODOLOGY}

The novel high voltage feedthrough is designed from solid PTFE and solid coper. It was equipped with covers on the right and left sides to protect from external electric field. The tools needed to form solid PTFE and copper into feedthrough are CNC machines and other mechanical devices. In addition, several tools to test the performance of feedthrough is needed, which are feedthrough, Cockcroft Walton generator, electrode, glass tube as holder, PVC, current meter to check the leakage current, and insulation hose to protect the connector from discharge.

\section{Design of HV Feedthrough}

The high voltage feedthrough for Arjuna 2.0 Cockcroft Walton works at a voltage of $17.5 \mathrm{kV}$. It connects the output of RF transformer oscillator (in the outside of horizontal vessel) to the input of voltage multiplier (inside of the horizontal vessel).

The design improvement was made based on the following considerations:

1. Increasing the length of the electron trajectory on the feedthrough surface to prevent flashover.

2. Increasing the thickness of the feedthrough to prevent a breakdown.

3. Preserving vacuum condition.

4. Reducing the electric field at the ground termination as much as possible.

5. Ensuring that the fastening bolts are capable of resisting force due to the pressure of the gas in the horizontal vessel.

Based on the literature and technical considerations, the feedthrough design was made as shown in Fig. 1. 


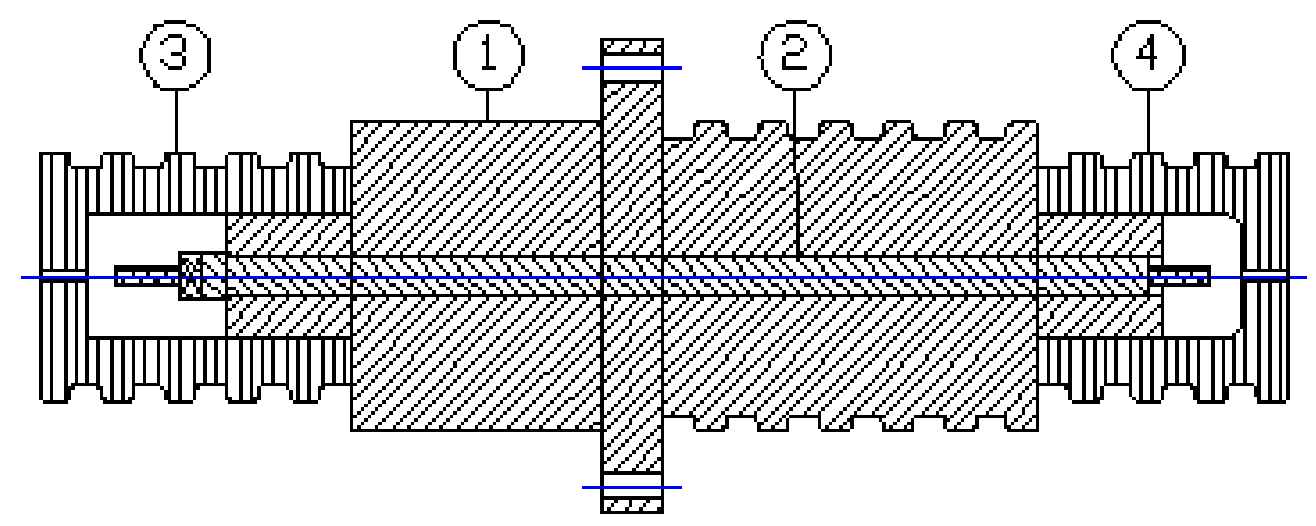

1. Feedthrough body

2. Solid Copper

3. Left cover ((the inside of horizontal vessel/pressurized SF6 condition)

4. Right cover (the outside of horizontal vessel/air condition)

Figure 1. Design of $17.5 \mathrm{kV}$ of feedthrough.

The body of the feedthrough was made from solid PTFE and mounted on the flange of Cockcroft Walton horizontal vessel. The left side of the flange was inserted into the vessel which have the same pressure as SF6. The right side of the flange was placed outside of the vessel (surrounded by open air). In the left and the right side of the feedthrough were covered to protect from external electric field.

The conductor part of the feedthrough was manufactured from a solid copper. The copper was selected due to its high conductivity and ease of construction. The conductor was placed on the center of the feedthrough and its length is longer than the body of the feedthrough.

\section{Simulation of Feedthrough Design}

The verification of the design was carried out by simulating the feedthrough using a software based on Finite Element Method (FEM) which is able to calculate the distribution of voltage and electric field [10]. An electromagnetic field simulation software, e.g. CST can be used to solve this problem [11, 12]. The simulation was done based on Maxwell equations [13].

In this research, covered and coverless feedthroughs were drawn and simulated in CST. Feedthrough covers were designed to reduce the electric field at the ground terminal as much as possible. To begin the simulation, the dimension of feedthrough body was calculated analytically. This calculation was conducted based on the dielectric strength of the insulator components of the feedthrough such as air, SF6, and PTFE. The calculation result was used to determine the dimension of feedthrough and is needed to make a technical drawing of 3D model in CST. After finishing the drawing, the material and condition were determined. PTFE was selected as the material of feedthrough body. The solid conductor is assumed to be made of PEC (Perfect Electric Conductor) and the voltage is set to be equal to $17500 \mathrm{~V}$. Grounded components such as the flange of the feedthrough and the body of Cockcroft Walton vessel are modeled with PEC with zero voltage. In the simulation, the feedthrough was simulated in two conditions, air condition for outside of vessel and SF6 condition for inside of vessel. The 3D models that have been designed would be meshed and analyzed by using CST electrostatic solver to obtain the voltage and electric field distribution.

\section{Construction and Performance Testing of Feedthrough}

After the feedthrough design has been verified by simulation result, it was constructed by CNC machines and other mechanical devices following its technical drawing. The next procedure was performance testing which was undertaken to determine their characteristics based on the design criteria. The procedure consist of ramping up the high voltage while constantly monitoring the current and the high voltage to verify the absence of discharges. 

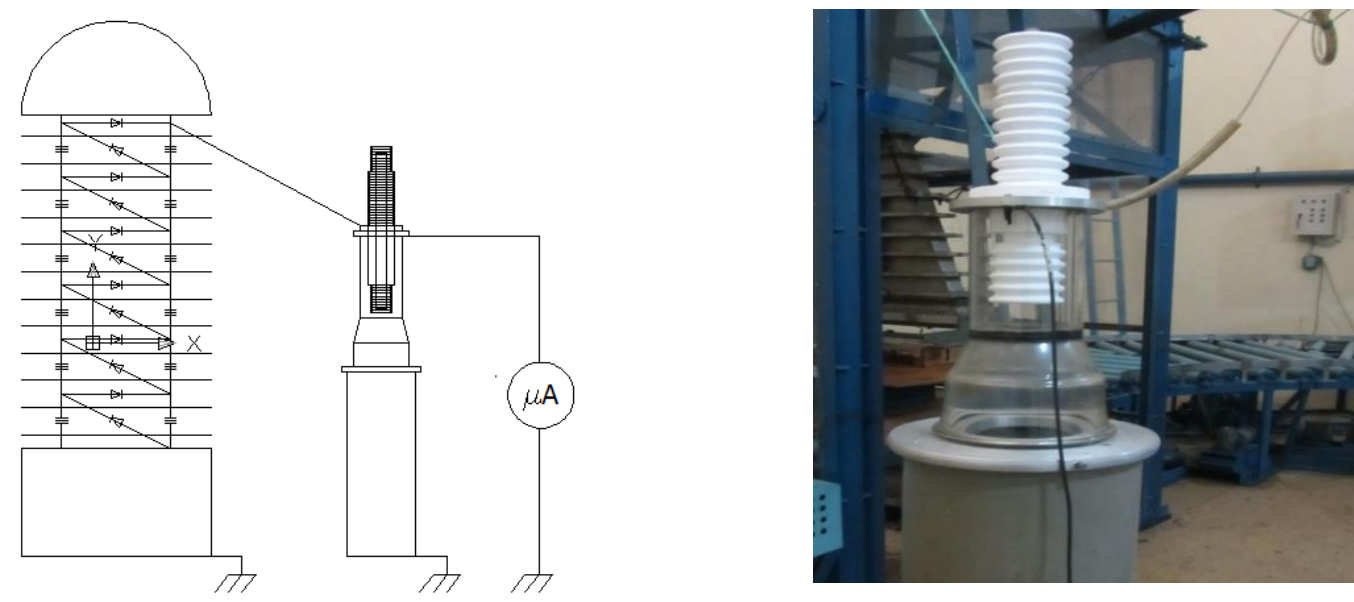

Figure 2. The equipment of feedthrough performance testing.

The initial testing was carried out by inserting the feedthrough into a pyrex glass tube connected to a PVC as an insulator. This will increase the distance that need to be traversed by electron to get to the ground, thus reducing the risk of discharge. The length of the pyrex glass and the PVC is 1.5 meters. Two electrodes were installed between the feedthrough and pyrex glass. The anode was connected to the positive power supply, while the cathode was connected serially and grounded to a microampere meter. The testing of feedthrough is shown in Fig. 2, the occurrence of discharges can be observed easily through the pyrex glass. The feedthrough breakdown or discharge can be indicated by the increase of the current that is monitored in the microampere meter.

\section{RESULT AND DISCUSSIONS}

\section{Simulation Results of Feedthrough Design}

The feedthrough was designed based on the dielectric strength of air, SF6, and PTFE. The length and diameter of feedthrough body are $500 \mathrm{~mm}$ and $99.5 \mathrm{~mm}$ respectively. In this case, the shortest radial distance between grounding and conductor (solid copper) is $43.25 \mathrm{~mm}$. On the feedthrough surface, the shortest distance between grounding with conductor is $253.5 \mathrm{~mm}$ for feedthrough body part that is inserted into the vessel, while the distance for feedthrough body part that connected with air was $>253.5 \mathrm{~mm}$. It was due to dielectric strength of air that is smaller than SF6 gas. The distance was calculated by considering the corrugated form of the surface. This will increase the surface area for a given volume, thus increasing the distance that need to be traversed by electron to get to the ground from the conductor.

Covers of feedthrough were installed on the left and the right side as shown as Fig. 1. They were intended to eliminate sharp edges in the connection between the high voltage cable and the feedthrough conductor. Sharp edges would increase the strength of electric field and causes discharge [14].

The feedthrough will be installed on the flange of Cockcroft Walton vessel as shown as Fig. 3. The separation distance between the flange and the body of Cockcroft Walton vessel is about $200 \mathrm{~mm}$ long. According to Fig. 3 , it was known that meshing process was succesfully done and then continued by electrostatic analysis.

The 3D Finite Element electrostatic analysis has been conducted by the CST software to determine voltage and electric field distribution of feedthrough. The maximum voltage of $17.5 \mathrm{kV}$ dc has been applied to feedthrough conductor. Fig. 4 shows the voltage distribution evaluated at the feedthrough. It can be seen that the voltage stress at the conductor is about $16 \mathrm{kV}$ to $17.5 \mathrm{kV}$, while the voltage stress at the flange is about $0 \mathrm{kV}$ to $3 \mathrm{kV}$. It is due to the flange is connected to ground. Generally, the radial voltage distribution is distributed uniformly. There are slight differences between the covered and coverless feedthrough. In the end of the feedthrough, the conductor voltage of covered feedthrough is lower than coverless feedthrough. 


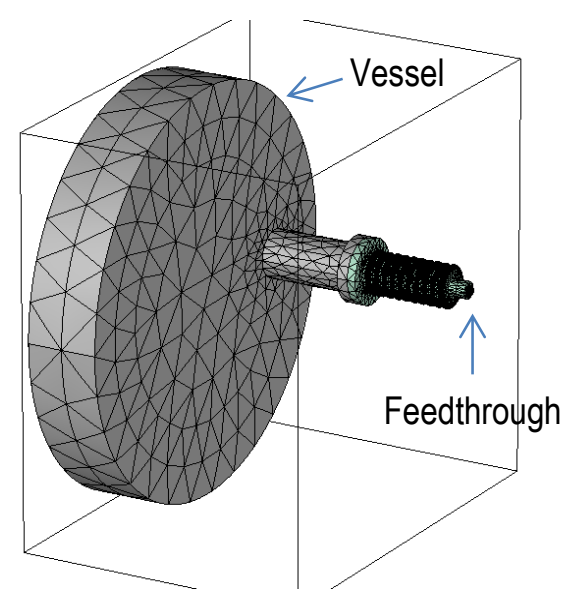

(a)



(b)

Figure 3. Meshing process of feedthrough. (a) Meshing process of coverless feedthrough, (b) Meshing process of coverless feedthrough.

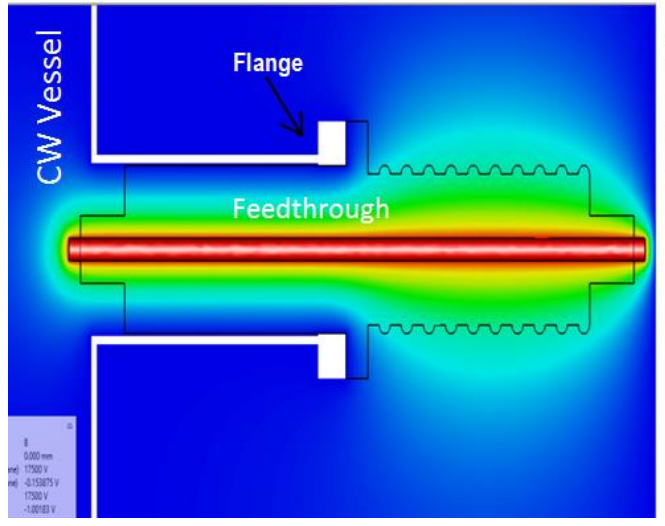

(a)

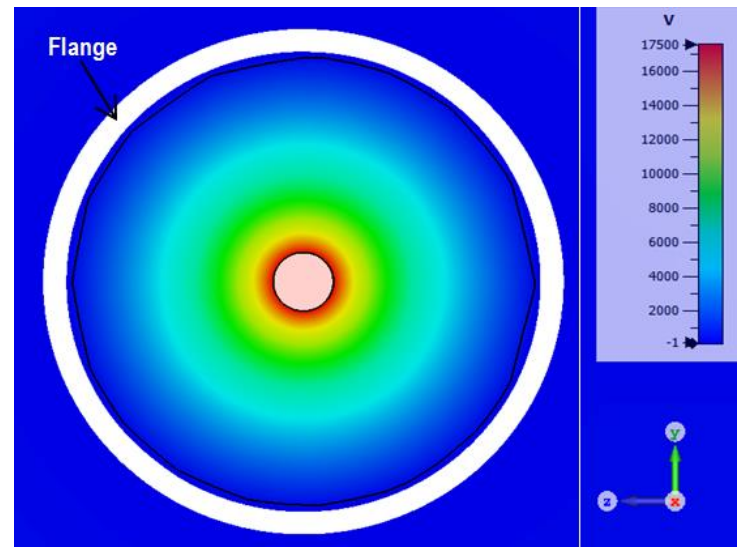

(c)


(b)

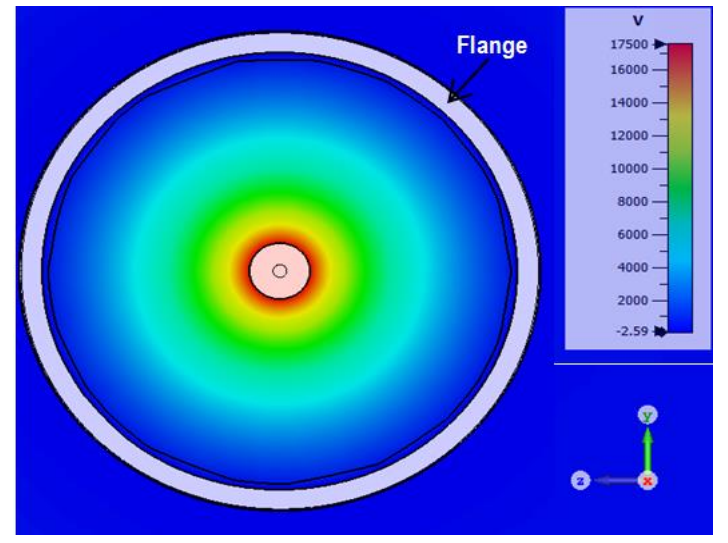

(d)

Figure 4. Voltage distribution of feedthrough. (a) Voltage distribution of coverless feedthrough cover (horizontal view), (b) Voltage distribution of covered feedthrough (horizontal view), (c) Voltage distribution of coverless feedthrough (radial view), (d) Voltage distribution of covered feedthrough (radial view). 


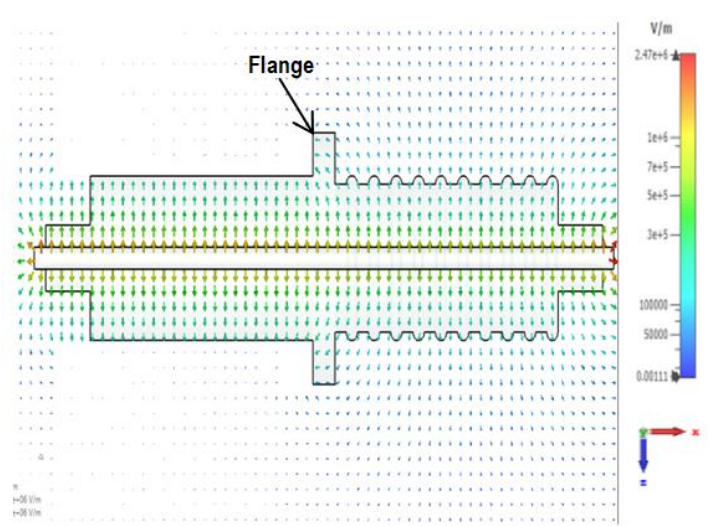

(a)

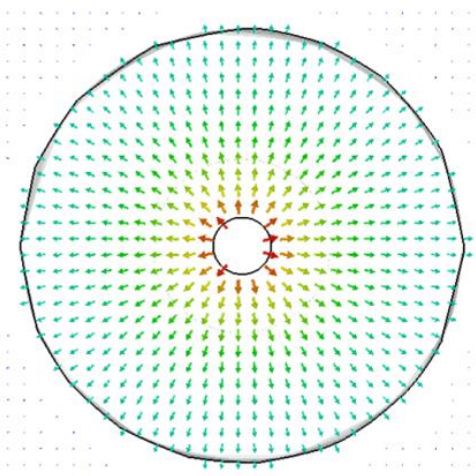

(d)

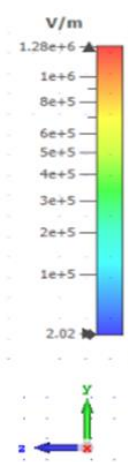



(b)

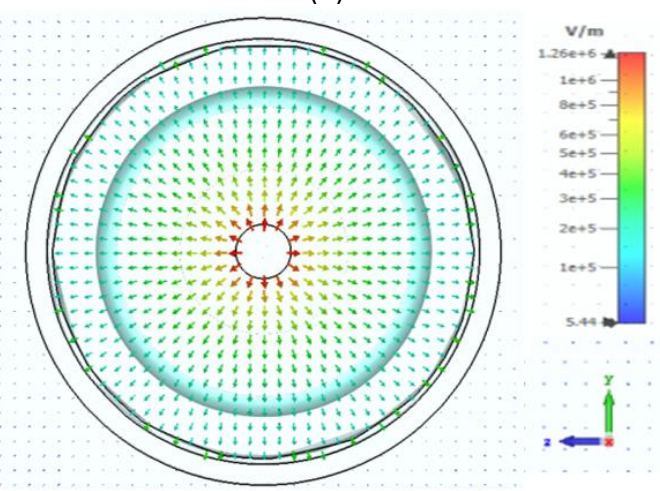

(e)

Figure 5. Electric field distribution of feedthrough. (a) Electric field distribution of coverless feedthrough cover (horizontal view), (b) Electric field distribution of covered feedthrough (horizontal view), (c) Electric field distribution of coverless feedthrough (radial view), (d) Electric field distribution of covered feedthrough (radial view).

Fig. 5 shows the electric field distribution of the feedthrough, that is concentrated on the conductor surface. The electric field gets weaker as it approaches the flange, because it is connected to ground [15]. In the coverless feedthrough, the highest electric field was $1.28 \times 10^{6} \mathrm{~V} / \mathrm{m}$, while the lowest electric field which occurred on feedthrough flange was around $2 \times 10^{5} \mathrm{~V} / \mathrm{m}$. When the feedthrough is covered, the magnitude of electric field decreases. The highest and lowest electric fields are $1.26 \times 10^{6} \mathrm{~V} / \mathrm{m}$ and around $1 \times 10^{5} \mathrm{~V} / \mathrm{m}$, respectively. In addition, the electric field in air conditions is relatively larger than the SF6 condition. That is because the relative permittivity of air is lower than the relative permittivity of SF6 [16]. From Fig. 5, it can be seen that no red arrow is present on the surface of the feedthrough. It means that there is no flashover occurs. In addition, no red arrow is present between the conductor and the ground which means that no discharge or breakdown occurs. According to these simulations, the feedthrough design is acceptable and the construction can be commenced.

\section{Performance Testing of Feedthrough}

After the feedthrough is constructed, it is then tested to observe its performance as shown in Fig. 2. The feedthrough was tested by varying the voltage from 0 to $120 \mathrm{kV}$ at temperature and humidity of $23^{\circ} \mathrm{C}$ and $64 \%$, respectively. That relativity high voltage is used to comply with safety requirement, where the upper limit is set to be at least six times higher than the operational value. The performance testing result is shown in Table 1.

According to Table 1, there is no leakage current when the feedthrough is supplied a voltage from 0 to 120 $\mathrm{kV}$. It means that there is no electron flowing from conductor to ground through the surface and PTFE. In other words, the feedthrough is ready to be installed and operated at a work voltage of $17.5 \mathrm{kV}$. 
Table 1. Performance Testing of Feedthrough.

\begin{tabular}{cc}
\hline Voltage $(\mathrm{kV})$ & Current Leakage $(\boldsymbol{\mu} \mathrm{A})$ \\
\hline 0 & 0 \\
$23.98 \pm 0.084$ & $0.4 \pm 0.025$ \\
$36 \pm 0.1$ & $0.6 \pm 0.030$ \\
$48 \pm 0.122$ & $0.6 \pm 0.040$ \\
$59.96 \pm 0.144$ & $0.2 \pm 0.010$ \\
$84.02 \pm 0.084$ & $0.6 \pm 0.035$ \\
$96.042 \pm 0.088$ & $0.8 \pm 0.045$ \\
$109.96 \pm 0.152$ & $0.4 \pm 0.030$ \\
$120 \pm 0.071$ & $0.2 \pm 0.015$ \\
\hline
\end{tabular}

\section{CONCLUSION}

Simulation of feedthrough using FEM software has been conducted to calculate voltage and electric field distributions. From this simulation, it was shown that the electric field of the covered feedthrough is lower than the coverless feedthrough. The probability of discharge occurrence for the covered feedthrough is smaller than the coverless one. After the simulation, this feedthrough has been tested up to $120 \mathrm{kV}$ and no discharge occurred. It means that this design can be operated at $17.5 \mathrm{kV}$ and it was successfully installed on Arjuna 2.0 Cockcroft Walton generator.

\section{ACKNOWLEDGMENTS}

The author would like to thank Umar Sahiful Hidayat, M.Eng. as the Head of PSTA-BATAN and the person in charge of the implementation of the 2020 DIPA for the implementation of the Arjuna 2.0 R\&D activities, and thanks to Dr. Imam Kambali as the person in charge of the Particle Physics Division, which has provided much guidance and direction in conducting research, as well as to Mr. Suhartono for technical assistance during this research, so that the writing of this paper can be completed.

\section{REFERENCES}

[1] Sutadi, Saefurrochman, E. Nuraini and Suprapto, Journal Physics Conference Series 1436, 012095, pp. 1 $7,2020$.

[2] S. Ihan and A. Ozdemir, "Design considerations of a $36 \mathrm{kV}$ silicone rubber wall," in The 19th International Symposium on High Voltage Engineering, pp. 1 - 5, 2015.

[3] N. Panklang, N. Phankong and K. Bhumkittipich, Energy Procedia 9, pp. 95 - 103, 2011.

[4] N. Umeda, M. Taniguchi, M. Kashiwagi, M. Dairaku, M. Hanada, H. Tobari, K. Watanabe, K. Sakamoto and T. Inoue, Fusion Engineering and Design 84, pp. 1875 - 1880, 2009.

[5] A. Simonin, H. de Esch, L. Doceul, L. Christin, F. Faisse and F. Villecroze, Fusion Engineering and Design 88, pp. 1-7, 2013.

[6] H. Tobari, T. Inoue, M. Taniguchi, M. Kashiwagi, N. Umeda, M. Dairaku, H. Yamanaka, K. Watanabe, K. Sakamoto, M. Kuriyama, J. Graceffa, L. Svensson, R. Hemsworth, M. Tanaka and D. Boilson, Fusion Engineering and Design 88 (6-8), pp. 975 - 979, 2013.

[7] S. Shah, D. Sharma, D. Parmar, H. Tyagi, K. Joshi, H. Shishangiya, M. Bandyopadhyay, C. Rotti and A. Chakraborty, Fusion Engineering and Design 113, pp. 6 - 15, 2016.

[8] R. Wang, G. Xu and Y. He, e-Polymers 17 (3), pp. 215 - 220, 2017.

[9] N. Riveiro, T. Abalde, P. Pou, R. Soto, J. del Val, R. Comesana, A. Badaoui, M. Boutinguiza and J. Pou, Applied Surface Science 515, 1459841 -10, 2020.

[10] M. Hassani, S. S. K. Madahi, H. F. Farahani and H. Sarabadani, Applied Mechanics and Materials 110-116, pp. $5184-5188,2012$.

[11] Y. H. Yeon, M. Ghergherehchi, X. Mu, K. M. M. Gad and J. S. Chai, Nuclear Instruments and Methodsin Physics Research A 763, pp. 510 - 516, 2014.

[12] E. Ebrahimibasabi and S. A. H. Feghhi, International Journal of Mass Spectrometry 386, pp. 1 - 5, 2015. 
[13] N. A. Rahman, M. Isa, M. N. K. H. Rohani, H. A. Hamid and M. M. A. B. Abdullah, Universal Journal of Electrical and Electronic Engineering 6 (5A), pp. 86 - 93, 2019.

[14] W. Lick, "Experiences in testing of AC and DC Bushings," in The 2013 Electrical Insulation Conference, pp. $304-307,2013$.

[15] N. A. Rahman, M. Isa, M. N. K. H. Rohani, H. A. Hamid and M. M. A. B. Abdullah, IOP Conference Series 551,012019 , pp. $1-5,2019$.

[16] L. Jin, Y. Xue, B. Zhao, J. Chen and W. Zhang, "Electric field calculation and insulation analysis of high voltage insulating bushing," in The 2nd International Conference on Electric Power Equipment - Switching Technology (ICEPE - ST), pp. 1-4, 2013. 